\title{
PENGARUH PIJAT (MASSAGE) BAYI TERHADAP KUALITAS TIDUR BAYI USIA 6 - 12 BULAN DI DESA PILANGPAYUNG KEC. TOROH KAB. GROBOGAN
}

\author{
Oleh; \\ Anita Lufianti ${ }^{1)}$, Christina Nur Widayati ${ }^{2)}$, Ninik Puji ${ }^{3)}$ \\ 1) Dosen STIKES An Nur Purwodadi, Email; kenzokensta@yahoo.com \\ 2) Dosen STIKES An Nur Purwodadi, Email; christina.widayati@yahoo.com \\ 3) Mahasiswa STIKES An Nur Purwodadi, Email; annurlppm@gmail.com
}

\begin{abstract}
ABSTRAK
Latar belakang; Pijat bayi yaitu suatu bentuk permainan gerakan pada bayi, untuk merangsang pertumbuhan dan perkembangan serta kemampuan pergerakan bayi secara optimal. Pijat bayi merupakan salah satu cara yang menyenangkan yang akan membuat perasaan nyaman bagi bayi. Saat ini berbagai terapi telah dikembangkan, baik terapi farmakologis maupun non farmakologis. Salah satu terapi non farmakologis untuk mengatasi masalah tidur bayi adalah pijat bayi, dengan menggunakan terapi pijat bayi sehingga kualitas tidur bayi akan lebih baik. Tujuan penelitian ini adalah untuk mengetahui pengaruh pijat (massage) bayi terhadap kualitas tidur bayi usia $6-12$ bulan di Desa Pilangpayung, Kec. Toroh, Kab. Grobogan.

Metode; Penelitian ini menggunakan desain quasi eksperimen dengan pendekatan non equivalent control group design with pretest and posttest. Teknik sampling yang digunakan adalah probability sampling dengan metode Simple Random Sampling dan didapatkan sampel berjumlah 40 responden.

Hasil; Berdasarkan analisis menggunakan uji Paired Sample T Test pada kelompok intervensi menunjukkan $p$ value 0.000 . sebab nilai $p$ velue $<0.05$ maka ada pengaruh pijat (massage) bayi terhadap kualitas tidur bayi usia 6-12 bulan di Desa Pilangpayung, Kec. Toroh, Kab. Grobogan. Pada kelompok kontrol hasil uji dengan menggunakan uji Wilcoxcon, didapatkan hasil $p$ value 0,000 , jika alpha $(\alpha)$ adalah 0,05 maka hasil yang didapatkan adalah $\mathrm{pV}<\alpha$ atau $0,000<0,05$ maka ada pengaruh pijat bayi (massage) terhadap kualitas tidur bayi.

Simpulan; Dari hasil penelitian tersebut dapat disimpulkan ada pengaruh pijat (massage) bayi terhadap kualitas tidur bayi usia $6-12$ bulan di Desa Pilangpayung, Kec. Toroh, Kab. Grobogan.
\end{abstract}

Kata kunci; Pijat (Massage) Bayi, Kualitas Tidur Bayi 


\title{
EFFECT OF MASSAGE (MASSAGE) THE QUALITY OF BABY SLEEPING BABY \\ AGED 6-12 MONTHS IN THE VILLAGE PILANGPAYUNG TOROH, GROBOGAN REGENCY
}

\author{
By; \\ Anita Lufianti ${ }^{1}$, Christina Nur $\mathrm{W}^{2}$, Ninik $\mathrm{P}^{3}$ \\ 1) Lecturer of STIKES An Nur Purwodadi, Email; kenzokensta@yahoo.com \\ 2) Lecturer of STIKES An Nur Purwodadi, Email; christina.widayati@yahoo.com \\ 3) Student of STIKES An Nur Purwodadi, Email; annurlppm@gmail.com
}

\begin{abstract}
Background: Infant massage is a form of motion games in infants, to stimulate growth and development and the ability of optimal infant movement. Infant massage is a fun way that will create a feeling of comfort for the baby. Nowadays various therapies have been developed, both pharmacologic and non-pharmacologic therapies. One non-pharmacologic therapy to overcome the problem of sleeping baby is a baby massage, using infant massage therapy so the baby sleep quality will be better. The purpose of this study was to determine the effect of the massage (massage) the baby to the quality of sleep of infants aged 6-12 months in Pilangpayung village, district. Toroh, Kab. Grobogan.

Methods: This study used a quasi-experimental design approach to non equivalent control group design with pretest and posttest. The sampling technique used is the probability sampling with simple random sampling method and obtained a sample of 40 respondents.

Result: Based on analysis using Paired Sample T Test in the intervention group showed $p$ value 0.000. For velue $p$ value <0.05 then there is the effect of the massage (massage) the baby to the quality of sleep of infants aged 6-12 months in Pilangpayung village, district. Toroh, Kab. Grobogan. In the control group of test results using Wilcoxcon test, the results obtained $p$ value of 0.000 , if the alpha $(\alpha)$ is 0.05 then the results obtained are $p V<\alpha$ or $0.000<0.05$, then there is the effect of infant massage (massage) on the quality of sleep baby. Conclusion: From these results we can conclude there is the influence of massage (massage) the baby to the quality of sleep of infants aged 6-12 months in Pilangpayung village, district. Toroh, Kab. Grobogan.
\end{abstract}

Keyword: Massage (Massage) Baby, Baby Sleep Quality 


\section{PENDAHULUAN}

Kualitas untuk mempersiapkan sumber daya manusia maka anak perlu dipersiapkan agar anak bisa tumbuh dan berkembang seoptimal mungkin sesuai dengan kemampuannya. Perkembangan anak akan optimal bila sejak bayi mendapatkan perhatian dan stimulasi perkembangan yang cukup. Bayi yang mendapat rangsangan secara tepat dan berkesinambungan akan mempengaruhi perkembangan otaknya. Perkembangan yang terjadi pada masa bayi adalah perkembangan kognisi dan sosioemosional. Perkembangan kognisi merupakan tahapan yang disebut sebagai sensori motor, tahapan sensori motor berlangsung sejak lahir hingga bayi berusia 2 tahun. Perkembangan mental pada tahapan ini ditandai oleh kemampuan bayi mengorganisasikan sensori dengan gerakan fisik dan tindakan yang dilakukannya (Kompas, 2009).

Berdasarkan data WHO tahun 2012 dicantumkan dalam jurnal Pediatrics, tercatat sekitar $33 \%$ bayi mengalami masalah tidur. Di Indonesia cukup banyak bayi yang mengalami masalah tidur, yaitu sekitar $44,2 \%$ bayi mengalami gangguan tidur seperti sering terbangun di malam hari. Namun lebih dari $72 \%$ orang tua menganggap gangguan tidur pada bayi bukan suatu masalah atau hanya masalah kecil, hal tersebut diungkapkan oleh sebuah penelitian pada tahun 2004-2005 yang dilaksanakan di lima kota besar di Indonesia (Jakarta, Bandung, Medan, Palembang dan Batam).

Menurut hasil penelitian Sekartini tahun 2004, yang dilakukan di 5 kota yaitu Jakarta, Bandung, Medan, Palembang dan Batam dengan jumlah responden 385 orang, diperoleh data $51,3 \%$ bayi mengalami gangguan tidur, $42 \%$ jam tidur malamnya kurang dari 9 jam, terbangun malam hari lebih dari tiga kali dan lama terbangun pada malam hari lebih dari satu jam.

Studi pendahuluan yang dilakukan di Dinas Kesehatan Grobogan tahun ( 2015 ). Di dapat hasil rekapan data Dinkes pada usia bayi 6 - 12 bulan berjumlah 578 bayi di bulan Februari, pada bulan Agustus 604 bayi. Kualitas tidur bayi mempengaruhi perkembangan bayi, sebab dengan tidur yang baik maka bayi akan tumbuh menjadi anak yang berkembang dengan baik pula. Bayi yang aktif dan tumbuh normal biasanya mempunyai waktu yang cukup untuk tidur. Aktifitas otak saat tidur lebih besar daripada saat keadaan terjaga, tubuh memproduksi hormon pertumbuhan tiga kali lebih banyak dibandingkan ketika dia terbangun. Indikasi perkembangan otak yang optimal adalah dengan berubahnya pola tidur menjadi lebih baik dan menurunnya rewel pada bayi sejak lahir (Hidayat, 2006). 
Cara yang dapat membantu bayi tidur lebih nyenyak antara lain dengan memandikan bayi dengan air hangat, melakukan aktivitas tenang seperti membaca dongeng, meninabobokan atau memperdengarkan musik tenang sebelum menidurkan bayi. Selain itu juga terdapat sebuah bentuk stimulasi untuk membantu bayi tidur nyenyak berupa pijat bayi yaitu suatu bentuk permainan gerakan pada bayi, untuk merangsang pertumbuhan dan perkembangan serta kemampuan pergerakan bayi secara optimal. Pijat bayi merupakan salah satu cara yang menyenangkan yang akan membuat perasaan nyaman bagi bayi. Saat ini berbagai terapi telah dikembangkan, baik terapi farmakologis maupun non farmakologis. Salah satu terapi non farmakologis untuk mengatasi masalah tidur bayi adalah pijat bayi. Pijat bayi adalah gerakan usapan lambat dan lembut pada seluruh tubuh bayi yang dimulai dari kaki, perut, dada, wajah, tangan dan punggung bayi. Pijat bayi merupakan salah satu bentuk rangsang raba. Rangsang raba adalah yang paling penting dalam perkembangan. Sensasi sentuhan merupakan sensori yang paling berkembang untuk menghilangkan ketegangan dan perasaan gelisah terutama pada bayi. Pijatan lembut akan membantu mengendorkan otot-ototnya sehingga bayi menjadi tenang dan tidurnya nyenyak (Liaw, 2000 dalam Hikmah, 2010).

Namun fakta menunjukkan masih banyak ibu-ibu yang enggan untuk melakukan pemijatan secara rutin kepada bayinya. Hal tersebut karena adanya perasaan takut salah memijat bayinya, badan bayi yang masih lemah serta tidak tahu bagaimana teknik memijat yang benar. Pengalaman yang didapat dari ibuibu kurang memberi perhatian pada bayi yang mempunyai masalah tidur, ibu-ibu menganggap masalah gangguan tidur merupakan hal yang biasa dan akan hilang dengan sendirinya. Kebanyakan ibu-ibu di desa melakukan pijat bayi saat bayi sakit saja, padahal manfaat pijat bayi sangat banyak salah satunya untuk meningkatkan tidur bayi (Subakti dan Anggraini, 2009).

Studi pendahuluan yang dilakukan oleh peneliti di Desa Pilangpayung diperoleh data dari 40 bayi yang berumur 6-12 bulan berkunjung melakukan imunisasi di Posyandu Desa Pilangpayung, Kec. Toroh, Kab. Grobogan. Keluhan yang dilaporkan oleh ibu berbeda-beda pada setiap bayi. Ada yang melaporkan sering terbangun ketika tidur pada malam hari karena ketika siang hari terlalu banyak melakukan aktivitas fisik ringan, seperti belajar merangkak, belajar mencoba duduk sebentar dengan ditopang, kondisi anaknya yang lagi sakit , bermain, dan suhu kamar yang terlalu 
panas. Dari 36 ibu yang membawa bayi ke posyandu, 20 orang mengatakan tahu atau pernah mendengar tentang pijat bayi namun tidak tahu bagaimana teknik memijat yang benar, 9 orang mengatakan sama sekali tidak tahu tentang pijat bayi, 7 orang mengatakan tahu tentang teknik memijat yang benar. Ibu-ibu menganggap masalah gangguan tidur (bayi tidak bisa tidur nyenyak / sering terbangun dan menangis dimalam hari) merupakan hal yang biasa dan akan hilang dengan sendirinya.

Berdasarkan latar belakang diatas peneliti tertarik untuk mengambil penelitian tentang "Pengaruh Pijat (Massage) Bayi terhadap Kualitas Tidur
Bayi Usia 6 - 12 Bulan di Desa Pilangpayung, Kec. Toroh,Kab. Grobogan"

\section{METODE}

Jenis penelitian yang digunakan dalam penelitian ini adalah Quasy Eksperimen dengan pendekatan non equivalent Control Group Design with Pre dan post test design. Populasi penelitian ini bayi usia 6 - 12 bulan sebanyak 40 responden dengan teknik sampling yang digunakan adalah probability sampling dengan metode simple random sampling. Uji normalitas data menggunakan uji Shapiro- Wilk dengan tingkat kepercayaan $95 \%$ kemudian dilakukan uji Paired t-test

\section{HASIL}

\section{Analisa Univariat}

Tabel 1; Distribusi Kualitas Tidur Sebelum dan Sesudah pemberian pijat (massage)

$$
(\mathrm{n}=20)
$$

\begin{tabular}{lccccc}
\hline Variabel & Mean & Std. & Skweness & Min & Max \\
& & & & & \\
\hline Sebelum & 3.55 & 1.504 & -.055 & 1 & 6 \\
\hline Sesudah & 6.85 & 1.424 & -.315 & 4 & 9 \\
\hline
\end{tabular}

Tabel 2; Distribusi kualitas tidur Sebelum dan Sesudah tanpa dilakukan pijat (massage)

$$
(\mathrm{n}=20)
$$

\begin{tabular}{lrllll}
\hline \multicolumn{1}{c}{ Variabel } & Mean & Std. & Skweness & Min & Max \\
\hline Sebelum & 2.90 & 1.483 & 0.404 & 1 & 6 \\
\hline Sesudah & 3.65 & 1.089 & 0.250 & 2 & 6 \\
\hline
\end{tabular}




\section{Analisa Bivariat}

Tabel 3; Hasil Uji Paired Samples T Test Kualitas Tidur

$$
\text { N } \quad \text { Rerata } \pm \text { s.b. } \quad \begin{gathered}
\text { PerbedaanRerata } P \\
\text { (IK95\%) }
\end{gathered}
$$

\begin{tabular}{lcccc}
\hline Pemberian Pijat (massage) & & & & \\
\hline Pijatpre & 20 & $3.55 \pm 1.504$ & -3.300 & 0.000 \\
Pijatpost & 20 & $6.85 \pm 1.424$ & $(-2.895)-(-3.705)$ & \\
\hline Tanpa Pijat (massage) & & & & \\
\hline Pijat pre Kontrol & 20 & $2.90 \pm 1.483$ & -.750 & 0.000 \\
Pijat post Kontrol & 20 & $3.65 \pm 1.089$ & $(-, 493)-(-1.007)$ & \\
\hline
\end{tabular}

Tabel 4; Hasil uji variansi

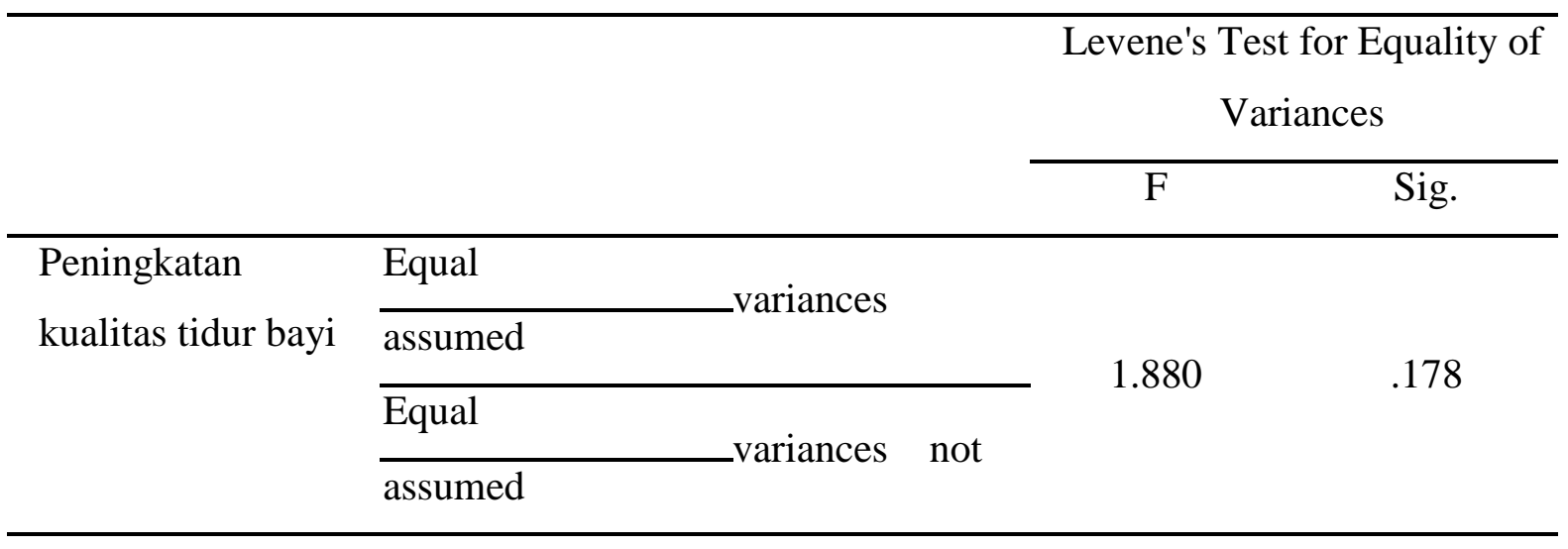

Tabel 5; Hasil uji independent sample t-test

\begin{tabular}{lcccc} 
& $\mathrm{N}$ & Rerata \pm s.b. & $\begin{array}{c}\text { Perbedaan Rerata } \\
(\text { IK95\%) }\end{array}$ & $P$ \\
\hline Perlakuan & 20 & $6.85 \pm 1.424$ & $3.200(4.014-$ & 0.000 \\
\hline Kontrol & 20 & $3.65 \pm 1.089$ & $2.386)$ & \\
\hline
\end{tabular}

\section{SIMPULAN}

1. Ada perbedaan antara pemberian Pijat (massage) dan tanpa Pijat (massage) untuk meningkatkan kualitas tidur bayi. Sebelum dilakukan
2. pijat (massage) didapatkan nilai rata-rata kualitas tidur sebelum pemberian pijat massage adalah $3.55 \%$ dan nilai rata-rata kualitas 
tidur setelah dilakukan pemberian pijat (massage) adalah $6.85 \%$.

3. Ada pengaruh pijat (massage) terhadap kualitas tidur bayi usia 6 12 bulan di Dusun Samben, Desa Pilangpayung. Untuk kualitas tidur bayi diketahui $p$-value $(0.000)<$ $(0,05)$, dengan demikian Ho ditolak dan $\mathrm{Ha}$ diterima berarti terdapat pengaruh yang bermakna.

\section{DAFTAR PUSTAKA}

Ubaya, Riadiani Lia. 2010. Hubungan Pijat Bayi dengan Kualitas Tidur Bayi Umur 6-12 Bulan di Desa Kertosari Kecamatan Singorojo Kabupaten Kendal.

Roesli, Utami. 2001. Pedoman Pijat Bayi (Edisi Revisi).PT. Trubus Agriwidya.Jakarta
Subakti, Y., \& Anggraini, D. R. 2012. Keajaiban Pijat Bayi dan Balita. Jakarta: PT Wahyu Media

Dahlan, M. S. 2010. Statistik untuk Kedokteran dan Kesehatan. Jakarta: Salemba Medika

Layyinatus Shofa, Yunani, Rose Hudhariani. 2014. Pengaruh Pijat Bayi Terhadap Kualitas Tidur Bayi Di Poliklinik Kesehatan Desa Purworejo Kecamatan Bonang Kabupaten Demak

Naimah Shadik. 2011. Pengaruh Pijat Bayi Terhadap Kualitas Tidur Bayi Usia 6-12 Bulan di Rumah Bersalin Rachmi Yogyakarta

Siti M Abdurrahman. 2015. Pemberian pijat (massage) dan kelompok kontrol tanpa pijat (massage) 